\title{
PENGARUH KUALITAS LAYANAN TERHADAP KEPUASAN NASABAH SMS BANKING PADA BANK NAGARI CABANG PEMBANTU RSUP DR M DJAMIL PADANG
}

\author{
David Suryanto, Nazaruddin Aziz \\ Sekolah Tinggi Ilmu Ekonomi "KBP" \\ nazaruddinaziz@akbpstie.ac.id \\ Davidsuryanto32@gmail.com
}

\begin{abstract}
This study examines the effect of service quality on customer satisfaction SMS Banking Bank Nagari Capem Dr.M.Djamil Hospital Padang. Quality of service in this research consists of 5 dimensions of tangible, reliability, responsiveness, assurance, empathy. The total population of this study as many as 391 people while the determination of samples in the study using this slovin formula and obtained a sample of 198 people. The results showed that the tangible. reliability responsiveness, no effect on customer satisfaction SMS Banking. Assurance and Emphaty affect the satisfaction of SMS Banking customers.
\end{abstract}

Keywords: tangible, reliability, responsiveness, assurance, empathy, customer satisfaction.

\section{PENDAHULUAN}

Perkembangan ilmu pengetahuan dan teknologi yang semakin canggih di era modern saat ini, membuat sebagian orang dituntut untuk mampu dan paham mengenai perkembangan tersebut. Hal ini nantinya akan berpengaruh besar terhadap kemajuan dan persaingan secara global. Bank merupakan lembaga kepercayaan yang berfungsi sebagai lembaga intermediasi membantu kelancaran system pembayaran dan juga sebagai lembaga atau sarana dalam pelaksanaan kebijakan pemerintah kegiatan bank akan meningkatkan investasi, produksi serta konsumsi barang dan jasa yang meningkatkan kegiatan ekonomi tersebut.

Agar dapat terus bertahan di dunia perbankan sebuah bank harus mampu memberikan pelayanan yang dapat memberikan kenyamanan dan kepuasan kepada nasabahnya. Pelayanan yang dimaksud adalah suatu kegiatan yang dilakukan dalam interaksi langsung antara seseorang dengan orang lain atau 
mesin secara fisik dan menyediakan kepuasan pelanggan untuk memberikan bantuan dan kemudahan kepada nasabah dalam mencapai tujuan tertentu (Susno dan Abdullah.2003). Sistem dan Kebijakan Perbankan di Indonesia. Pusat Pendidikan dan Studi Kebanksentralan (PPSK) Bank Indonesia.Pelayanan menjadi sangat penting bagi sebuah bank dalam rangka memasarkan produk - produknya kepada nasabah, karena senantiasa berhubungan dengan masyarakat yang memiliki keanekaragaman kepentingan dan tujuan.

Bryant (1996) menyatakan bahwa kepuasan pelanggan yang tinggi terjadi apabila nilai yang dirasakan dan kualitas yang dirasakan melebihi harapan pelanggan. Hal ini bermakna bahwa semakin tinggi kepuasan yang dirasakan oleh nasabah maka semakin tinggi kecintaan pelanggan atau nasabah atas produk yang ditawarkan oleh bank tersebut.

Cronin dan Taylor (1992) menyatakan bahwa kualitas pelayanan berpengaruh terhadap kepuasan pelanggan. Semakin bagus kualitas pelayanan yang diberikan oleh perusahaan perbankan maka semakin puas nasabah atas produk bank tersebut. Kualitas pelayanan tersebut ada 5 dimesi utama yaitu bukti langsung, keandalan, daya tanggap, jaminan, dan empati.

Dalam rangka meningkatkan pelayanan dan memberikan kemudahan kepada nasabah dalam melakukan transaksi perbankan di PT. Bank Pembangunan Daerah Sumatera Barat, maka dipandang perlu mengembangkan Sistem Informasi Teknologi yang mampu menghasilkan tingkat layanan yang lebih cepat, terpercaya, dan handal, serta dengan jangkauan layanan yang lebih luas tanpa dibatasi dengan kendala wilayah dan waktu. Salah satu sarana yang dibutuhkan untuk itu adalah dengan menyediakan Short Message System (SMS)Banking.

Perkembangan SMS Banking Bank Nagari pada tahun 2016 tidak terjadi kenaikan disetiap bulannya tetapi pada beberapa bulan terakhir di tahun 2016 terjadi penurunan. Sedangkan pada tahun 2017 terjadi pertumbuhan yang sangat signifikan di bulan April yaitu sebesar 128\% dibandingkan dengan bulan Maret atau bertumbuh sebanyak 41 orang pengguna. Pertumbuhan ini dikarenakan adanya fitur baru yang ditawarkan oleh Bank Nagari sebagai pendukung dari SMS Banking yaitu SMS Notification.Yang mana setiap pendaftaran SMS Banking juga harus mengaktifkan fitur SMS Banking sekaligus sebagai bentuk pemasaran dari pihak bank untuk memasarkan produknya.

Dari uraian diatas, terlihat bahwa Bank Nagari perlu meningkatkan kualitas pelayanannya terutama untuk produk SMS Banking dengan memperhatikan strategi yang jitu.Hal ini sangat penting untuk dapat menjadikan perusahaan sebagai market leader dan yang lebih penting tetap bertahan dalam industri.Hal inilah yang menjadi daya tarik penulis untuk melakukan penelitian dan menuangkan dalam bentuk proposal dengan judul "Pengaruh Kualitas Layanan Terhadap Kepuasan Nasabah SMS BankingPada Bank Nagari Cabang Pembantu RSUP Dr M Djamil Padang”.

Menurut Kasmir (2008:54) secara umum pengertian pemasaran bank adalah suatuproses untuk menciptakan dan mempertukarkan produk atau jasa bank yang 
ditujukan untuk memenuhi kebutuhan dan keinginan nasabah dengan cara memberikan kepuasan.Pentingnya pemasaran dilakukan dalam rangka memenuhi kebutuhan dan keinginan masyarakat akan suatu produk dan jasa. Pemasaran juga bisa dilakukan dalam rangkamenghadapi pesaing dari waktu ke waktu yang semakin meningkat.Para pesaing justru semakin gencar melakukan usaha pemasaran dalam rangka memasarkan produknya.

SMS banking merupakan bagian dari electronic banking channel dan juga merupakaninovasi dari jenis rekening tabungan dan atau rekening giro rupiah.Sebagai system layanan yang bersumber pokok pada kedua rekening tersebut, maka salah satu syarat bagi nasabahyang menginginkan layanan SMS banking ini terlebih dulu harus mempunyai rekening tabungan dan atau rekening giro serta harus rnempunyai sarana penunjang yaitu ponsel.

Pelayanan adalah suatu aktivitas atau tindakan tak kasat mata dari satu pihak kepada pihak lain. Pada umumnya jasa atau pelayanan diproduksi dan dikonsumsi secara bersamaan dimana interaksi antara pemberi jasa dan penerima jasa mempengaruhi hasil jasa tersebut. Definisi kualitas pelayanan menurut Parasuraman, et al sebagaimana dikutip oleh Thomas Stefanus Kaihatu (2011),mengatakan bahwa, memberikan batasan tentang pengertian:

Service quality is the foundation for service marketing because the core product, the performance is what customer buy. A strong service concept gives thecompanies the opportunity to compete for customer, strategi confidence and reinforcing branding,advertising, selling and pricing. An inovator"s strategi of service quality is usually more difficult to imitate than it"s service concept. This is because quality service comes from inspired leadership throught out an organization, a customer-minded corporate culture, excellent service-system design, the effective use of information and technology, and other factors that develop in company.

Artinya kualitas pelayanan merupakan dasar bagi pemasaran jasa,karena inti produk yang dipasarkan adalah suatu kinerja (yang berkualitas), dan kinerja lah yang dibeli oleh pelanggan, oleh karena itu kualitas kinerja pelayanan merupakan dasar bagi pemasaran jasa, konsep pelayan yang baik akan memberikan peluang bagi perusahaan untuk bersaing dalam merebutkonsumen. Sedangkan kinerja yang baik (berkualitas)dari sebuah konsep 8 pelayanan menimbulkan situasi yang kompetitif dimana hal tersebut dapat diimplementasikan melalui strategi untuk meyakinkan pelanggan, memperkuat image tentang merek, iklan, penjualan, dan penentuan harga.

Parasuraman (1994:246) mengemukakan lima dimensi kualitas jasa. Kelima dimensitersebut adalah reliability (kehandalan), responsiveness (daya tanggap), assurance (jaminan),empathy (empati), dantangible (produk-produk fisik).

1) Tangibles (produk-produk fisik) adalah suatu bentuk penampilan fisik, peralatan personal, media komunikasi dan hal - hal yang lainnya yang bersifat fisik

2)Reliability (keandalan) adalah suatu kemampuan untuk memberikan jasa yang dijanjikan dengan akurat dan terpercaya. Artinya pelayanan yang diberikan handal dan bertanggung jawab, karyawan sopan dan ramah. Ketetapan dan keakuratan inilah 
yang akan menumbuhkan kepercayaan konsumen terhadap lembaga penyedia layanan jasa.

3) Responsiveness (daya tanggap) adalah suatu respon/kesigapan karyawan dalam membantu konsumen dan memberikan pelayanan yang cepat dan tanggap. Kecepatan dan ketepatan pelayanan berkenaan dengan profesionalitas,profesionalitas ini yang ditunjukkan melalui kemampuannya dalam memberikan pelayanan kepada konsumen.

4)Assurance (jaminan) adalah kemampuan karyawan atas pengetahuan terhadap produk secara tepat, kualitas, keramah - tamahan, perkataan atau kesopanan dalam memberikan pelayanan, ketrampilan dalam memberikan informasi dan kemampuan dalam menanamkan kepercayaan konsumen terhadap perusahaan. Dalam memberikan pelayanan kepada konsumen hendaknya selalu memperhatikan etika berkomunikasi, supaya tidak melakukan manipulasi pada waktu menawarkan produk maupun berbicara dengan konsumen. Baik buruknya layanan yang diberikan akan menentukan keberhasilan lembaga atau perusahaan pemberi jasa layanan.

5) Empathy (perhatian) adalah kemampuan perusahaan dalam memberikan perhatian yang bersifat individual atau pribadi kepada para konsumennya.

Kepuasan pelanggan menurut Richard Gerson (2002:3) adalah "persepsi pelanggan bahwa harapannya telah terpenuhi atau terlampaui".Sedangkan, menurut Kotler dan Armstong (2008:16) mengungkapkan bahwa kepuasan pelanggan adalah "tingkatan dimana kinerja anggapan produk sesuai dengan ekspektasi pembeli".

1) Hipotesis 1

H1: Kemampuan fisik (Tangible) berpengaruh signifikan terhadap kepuasan nasabah pada Bank Nagari Capem RSUP DR. M Djamil.

2) Hipotesis 2

$\mathrm{H} 2$ :Keandalan (Reliability) berpengaruh signifikan terhadap kepuasan nasabah pada Bank Nagari Capem RSUP DR.M Djamil.

3) Hipotesis 3

H3: Daya tanggap (Responsiveness) berpengaruh signifikan terhadap kepuasan nasabah pada Bank Nagari Capem RSUP DR.M Djamil.

4) Hipotesis 4

H4: Jaminan (Assurance) berpengaruh signifikan terhadap kepuasan nasabah pada Bank Nagari Capem RSUP DR.M Djamil.

5) Hipotesis 5

H5: Empati (Empathy) berpengaruh signifikan terhadap kepuasan nasabahpada Bank Nagari Capem RSUP DR.M Djamil.

Berdasarkan rumusan masalah dan tujuan yang telah dijelaskan pada bab sebelumnya, maka penelitian ini tergolong penelitian kuantitatif.

Populasi dalam penelitian ini adalah nasabah yang menggunakan layanan SMS banking Pada Bank Nagari Capem RSUP DR.M. Jamil Padang dengan total nasabah per 31 Mei 2017 sebanyak 391 orang. 
Sedangkan metode penentuan sampelyang digunakan adalah dengan teknik random sampling yaitu teknik penarikan sampel secara acak terhadap nasabah yang menggunakan layanan SMS Banking.

Data dalam penelitian ini dari segi jenisnya tergolong data subjek yaitu data berupa pengalaman,pendapat, dan persepsi responden.

Sumber data dalam penelitian ini adalah data primer. Data tersebut langsung diperoleh dari nasabah SMS Banking Bank Nagari Capem RSUP DR.M.Djamil Padang dengan menggunakan daftar pernyataan dalam bentuk kuisioner guna mengumpulkan informasi dari objek penelitian tersebut.

Teknik pengumpulan data adalah cara yang digunakan untuk memperoleh data penelitian. Untuk memperoleh data yang diperlukan dalam penelitian ini yaitu dengan menggunakan angket (kuisioner). Kuisioner merupakan teknik pengumpulan data yang dilakukan dengan memberikan seperangkat pertanyaan atau pertanyaan tertulis kepada responden untuk menjawabnya. Kuisioner disebarkan secara langsung pada responden. Untuk mengantisipasi rendahnya tingkat respon (respond rate).

Uji validitas merupakan tingkat kemampuan suatu instrument dalam mengungkapkan sesuatu menjadi sasaran pokok pengukuran yang dilakukan dengan instrument tersebut.

Uji reliabilitas merupakan alat untuk mengukur suatu kuisioner yang merupakan indikator dari variabel. Suatu kuisioner dikatakan reliabel atau handal jika jawaban seseorang terhadap pernyataan adalah konsisten dari waktu ke waktu.

Sebelum melakukan pengujian terhadap hipotesis, terlebih dahulu dilakukan uji normalitas untuk mengetahui metode statistik yang akan digunakan.

Uji multikolinearitas ini bertujuan untuk menguji apakah model regresi ditemukan adanya korelasi antar variabel bebas atau indepenen.

Menurut Imam (2007:105), uji heterokedastisitas bertujuan untuk menguji apakah dalam model regresi terjadi ketidaksamaan varian dari residual satu pengamatan ke pengamatan yang lain (nilai errornya).

Analisis ini bertujuan menggambarkan masing-masing variabel dalam bentuk hasil distribusi frekuensi, kemudian dilakukan analisis mean, standar deviasi, tingkat capaian responden dan koefisien serta memberikan interpretasi analisis tersebut.

Koefisien determinasi $\left(\mathrm{R}^{2}\right)$ pada intinya mengukur seberapa jauh kemampuan model dalam menerangkan variasi variabel terikat.

Alat analisis regresi berganda digunakan untuk melihat pengaruh beberapa variabel independen terhadap variabel dependen

Uji $\mathrm{F}$ dilakukan bertujuan untuk menguji apakah hasil analisis regresi berganda modelnya sudah fix atau belum dan untuk dapat mengetahui pengaruh antara variabel bebas dan variabel terikat secara keseluruhan atau secara simultan.

Pengujian ini bertujuan untuk mengetahui hubungan yang signifikan dari masing-masing variabel bebas terhadap variabel terikatnya. Dari 198 eksemplar kuesioner yang disebar ternyata hanya hanya 139 yang kembali. Hal ini disebabkan 
karena lokasi nasabah yang berjauhan dan alasan lain yang tidak menentu. Dari 139 kuesioner kembali yang dapat di olah hanya 131 eksemplar kuesioner.

Berdasarkan hasil yang diperoleh dari 131 responden yang kuesioner dapat di olah maka sebanyak 65 orang $(49,6 \%)$ responden adalah laki-laki, sedangkan 66 $(50,4 \%)$ orang reponden adalah perempuan.

Berdasarkan pengolahan data maka usia responden mayoritas adalah 20-29 tahun dan 41-50 tahun yang mana sebanyak 36 orang (27,5\%). Sedangkan kisaran 1619 tahun hanya 1 orang. $(0,8 \%)$.

Berdasarkan tingkat pendidikan maka paling banyak responden adalah Diploma sebanyak 44 orang $(33,6 \%)$, sedangkan paling sedikit adalah tamatan SD sebesar 5 orang $(3,8 \%)$. Berikut tabel olahan data dengan SPSS 2, yaitu :

Berdasarkan pekerjaan responden maka paling banyak berprofesi sebagai PNS sebanyak 41 orang $(31,3 \%)$, sedangkan paling sidikit adalah pelajar dan lain-lain sebanyak 2 orang $(1,5 \%)$.

Berdasarkan lama menjadi nasabah maka paling banyak dari semua responden adalah rentang waktu 3-5 tahun sebanyak 55 orang (42\%), sedangkan paling sedikit adalah $<1$ tahun sebanyak 3 orang $(2,3 \%)$.

Berdasarkan tingkat pendapatan setiap bulan maka paling banyak menjawab rentang Rp 1.000.000- Rp 2.000.000 sebanyak 38 orang (29\%), sedangkan paling sedikit menjawab rentang Rp 5.000.000-Rp 10.000.000 sebanyak 12 orang (9,2\%).

Uji Validitas dimaksudkan untuk mengetahui instrumen dalam mengukur apa yang hendak diukur. Kuisioner yang kembali 139 eksemplar kuesioner dan yang dapat diolah sebanyak 131 eksemplar kuesioner. Untuk melihat validitas kuesioner maka peneliti menggunakan model Product Moment dan diperoleh hasil sebagai berikut:

\begin{tabular}{|l|l|}
\hline Variabel & $\mathrm{R}$ hitung \\
\hline Tangible (X1) & 0,499 \\
\hline Reliability (X2) & 0,324 \\
\hline Responsiveness (X3) & 0,365 \\
\hline Assurance (X4) & 0,676 \\
\hline Empathy (X5) & 0,694 \\
\hline Kepuasan Nasabah (Y) & 0,419 \\
\hline
\end{tabular}

$\mathrm{r}$ tabel untuk $\mathrm{n}=131$ dengan sig $5 \%$ sebesar 0,17 . Jadi berdasarkan tabel di atas semua item pertanyaan ke enam variabel dinyatakan valid karena tidak ada yang berada di bawah 0,17 . Sehingga kuesioner ini layak untuk dijadikan item pertanyaan penelitian

\begin{tabular}{|l|l|l|}
\hline Variabel & Nilai Cronbach Alpha & Keterangan \\
\hline Tangible (X1) & 0,753 & Reliabel \\
\hline Reliability (X2) & 0,746 & Reliabel \\
\hline Responsiveness (X3) & 0,788 & Reliabel \\
\hline Assurance (X4) & 0,801 & Reliabel \\
\hline Empathy (X5) & 0,797 & Reliabel \\
\hline
\end{tabular}




\section{\begin{tabular}{|l|l|l} 
Kepuasan Nasabah $(Y)$ & 0,791 & Reliabel
\end{tabular}}

Hasil tersebut menunjukkan bahwa semua variabel mempunyai Cronbach Alpha yang cukup besar yaitu di atas 0,60 sehingga dapat dikatakan semua konsep pengukur masing-masing variabel dari kuisioner adalah reliabel sehingga untuk selanjutnya item-item pada masing-masing konsep variabel tersebut layak digunakan sebagai alat ukur.

\section{Coefficients $^{\mathrm{a}}$}

\begin{tabular}{|c|c|c|c|c|c|c|}
\hline \multirow{2}{*}{\multicolumn{2}{|c|}{ Model }} & \multicolumn{2}{|c|}{$\begin{array}{l}\text { Unstandardized } \\
\text { Coefficients }\end{array}$} & \multirow{2}{*}{\begin{tabular}{|l}
$\begin{array}{l}\text { Standardized } \\
\text { Coefficients }\end{array}$ \\
Beta \\
\end{tabular}} & \multirow[t]{2}{*}{$\mathrm{t}$} & \multirow[t]{2}{*}{ Sig. } \\
\hline & & B & Std. Error & & & \\
\hline \multirow{6}{*}{1} & (Constant) & 1,377 & ,664 & & 2,074 &, 040 \\
\hline & Tangibles &,- 043 & ,045 &,- 110 &,- 963 & ,338 \\
\hline & Reliability &,- 013 &, 042 &,- 028 &,- 301 & ,764 \\
\hline & Responsiveness &,- 023 & ,037 &,- 064 &,- 626 & ,532 \\
\hline & Assurance &, 108 & ,037 & ,298 & 2,952 & ,06 \\
\hline & Empathy & ,024 & ,040 &, 056 &, 604 &, 547 \\
\hline
\end{tabular}

a. Dependent Variable: RES2

Berdasarkan Tabel diatas dapat dilihat bahwa hasil perhitungan masingmasing variabel menunjukkan bahwa level sig $>0,05$ yaitu $0,338>0,05$ untuk varibel tangible, 0,764 > 0,05 untuk variabel Reliability, 0,532 >0,05 untuk variabel Responsiveness, 0,06 > 0,05 untuk variabel Assurance, 0,547>0,05 untuk variabel Empathy. Sehingga penelitian ini bebas dari gejala heterokedastisitas dan layak untuk diteliti.

. Nilai koefisien determinasi dapat dilihat pada tabel dibawah ini:

\section{Model Summary ${ }^{\mathrm{b}}$}

\begin{tabular}{|l|l|l|l|l|}
\hline $\begin{array}{l}\text { Mode } \\
1\end{array}$ & R & R Square & $\begin{array}{l}\text { Adjusted } \\
\text { Square }\end{array}$ & Std. Error of the Estimate \\
\hline 1 &, $860^{\mathrm{a}}$ &, 739 &, 729 & 2,49907 \\
\hline
\end{tabular}

a. Predictors: (Constant), Emphaty, Responsiveness, Reliability, Assurance, Tangible

b. Dependent Variable: Kepuasan Nasabah

Berdasarkan tabel di atas terlihat bahwa besarnya nilai adjusted $R$ square adalah 0,729 yang bermakna bahwa kemampuan variabel Tangible (X1), Reliability (X2), Responsiveness (X3), Assurance (X4), dan Empathy (X5 )menjelaskan variabel Kepuasan Nasabah (Y) sebesar 72,9\% sedangkan sisanya sebesar 27,1\% dipengaruhi oleh variabel diluar model penelitian.

Ringkasan hasil pengolahan data dengan menggunakan program SPSS 21 tersebut adalah sebagai berikut 


\section{Coefficients $^{\mathrm{a}}$}

\begin{tabular}{|ll|l|l|l|l|l|}
\hline \multirow{2}{*}{ Model } & \multicolumn{2}{|l|}{$\begin{array}{l}\text { Unstandardized } \\
\text { Coefficients }\end{array}$} & \multicolumn{2}{l|}{$\begin{array}{l}\text { Standardized } \\
\text { Coefficients }\end{array}$} & & \multirow{2}{*}{ Sig. } \\
\cline { 2 - 5 } & B & Std. Error & Beta & & \\
\hline \multirow{4}{*}{1 Constant) } & $-2,814$ & 1,042 & & $-2,699$ &, 008 \\
& Tangible &, 071 &, 070 &, 061 & 1,002 &, 318 \\
& Reliability &, 076 &, 065 &, 058 & 1,165 &, 246 \\
& Responsiveness &, 094 &, 058 &, 089 & 1,635 &, 105 \\
& Assurance &, 688 &, 057 &, 645 & 11,987 &, 000 \\
& Emphaty &, 356 &, 063 &, 279 & 5,683 &, 000 \\
\hline
\end{tabular}

a. Dependent Variable: Kepuasan Nasabah

Berdasarkan tabel di atas dapat dianalisis model estimasi sebagai berikut:

\section{$\mathrm{Y}=-\mathbf{2 , 8 1 4}+\mathbf{0 , 0 7 1 X 1}+\mathbf{0 , 0 7 6} \mathrm{X} 2+0,094 \mathrm{X3}+\mathbf{0 , 6 8 8 X} 4+0,356 \mathrm{X5}$}

Keterangan:

$\mathrm{Y}=$ Kepuasan Nasabah

$\mathrm{X} 1=$ Tangible

$\mathrm{X} 2=$ Reliability

$\mathrm{X} 3=$ Responsiveness

$\mathrm{X} 4=$ Assurance

$\mathrm{X} 5=$ Empathy

Dari persamaan diatas dapat dijelaskan bahwa:

a) Nilai konstanta sebesar -2,814 ini mengidentifikasikan bahwa jika variabel independen yaitu tangible, reliability, responsiveness, assurance, dan empathy adalah 0, maka nilai kepuasan nasabah adalah sebesar konstanta -2.814

b) Koefisien tangible sebesar 0,071 ini mengidentifikasikan setiap peningkatan tangible sebesar satu satuan akan mengakibatkan peningkatan kepuasan nasabah sebesar 0,071 dengan asumsi variabel lain konstan.

c) Koefisien reliability sebesar 0,076 mengidentifikasikan setiap peningkatan reliability satu satuan akan mengakibatkan peningkatan kepuasan nasabah sebesar 0,076 dengan asumsi variabel lain konstan.

d) Koefisien responsiveness sebesar 0,094 mengidentifikasikan setiap peningkatan responsiveness satu satuan akan mengakibatkan peningkatan kepuasan nasabah sebesar 0,094 dengan asumsi variabel lain konstan. 
e) Koefisien assurance sebesar 0,688 mengidentifikasikan setiap peningkatan assurance satu satuan akan mengakibatkan peningkatan kepuasan nasabah sebesar 0,688 dengan asumsi variabel lain konstan

f) Koefisien empathy sebesar 0,356 mengidentifikasikan setiap peningkatan empathy satu satuan akan mengakibatkan peningkatan kepuasan nasabah sebesar 0,356 dengan asumsi variabel lain konstan.

ANOVA $^{\mathrm{a}}$

Berikut tabel Uji F hasil olahan SPSS 21, yaitu:

\begin{tabular}{|l|l|l|l|l|l|}
\hline Model & $\begin{array}{l}\text { Sum of Df } \\
\text { Squares }\end{array}$ & $\begin{array}{l}\text { Mean } \\
\text { Square }\end{array}$ & F & Sig. \\
\hline $\begin{array}{l}\text { Regressi } \\
\text { on }\end{array}$ & 2215,528 & 5 & 443,106 & 70,950 &, $000^{\mathrm{b}}$ \\
$\begin{array}{l}\text { Residual } \\
\text { Total }\end{array}$ & 780,670 & 125 & 6,245 & & \\
\hline
\end{tabular}

a. Dependent Variable: Kepuasan Nasabah

b. Predictors: (Constant), Emphaty, Responsiveness, Reliability , Assurance, Tangible

Uji t statistik (t-test) bertujuan untuk mengetahui hubungan yang signifikan dari masing-masing variabel bebas terhadap variabel terikatnya. Pengujian hipotesis secara parsial dilakukan dengan cara membandingkan nilai $t_{\text {hitung }}$ dengan nilai $t_{\text {tabel }}$. Nilai $\mathrm{t}_{\text {tabel }}$ adalah $a=a=0,05$ dengan derajat bebas $(\mathrm{db})=\mathrm{n}-\mathrm{k}=131-7=125$ adalah 1,98, berdasarkan hasil analisis pada tabel 16 maka dapat diketahui pengaruh variabel independen secara parsial terhadap variabel dependen adalah sebagai berikut:

Pengujian hipotesis dilakukan dengan membandingkan thitung dengan nilai $t_{\text {tabel }}$. Hipotesis diterima jika $t_{\text {hitung }}>t_{\text {tabel }}$ atau nilai sig $<0,05$. Nilai $t_{\text {abel }}$ pada 0,05 adalah 1,98. Untuk variabel tangible $\left(\mathrm{X}_{1}\right)$ nilai $\mathrm{t}_{\text {hitung }}$ adalah 1,002 dan nilai sig adalah 0,318 . Dengan demikian dapat dikatakan bahwa $t_{\text {hitung }}<t_{\text {tabel }}$ yaitu $1,002<1,98$ atau nilai signifikasi $0,318>0,05$. Nilai koefisien ${ }^{\beta \beta}$ dari variabel $X_{1}$ bernilai Positif yaitu 1,002. Hal ini menunjukkan bahwa penelitian ini tidak dapat membuktikan tangible $\left(\mathrm{X}_{1}\right)$ berpengaruh positif terhadap tingkat kepuasan nasabah. Dengan demikian hipotesis pertama $\left(\mathrm{H}_{1}\right)$ ditolak.

Pengujian hipotesis dilakukan dengan membandingkan thitung dengan nilai $t_{\text {tabel }}$. Hipotesis diterima jika $t_{\text {hitung }}>t_{\text {tabel }}$ atau nilai sig $<0,05$. Nilai $t_{\text {abel }}$ pada 0,05 adalah 1,98. Untuk variabel reliability $\left(\mathrm{X}_{2}\right)$ nilai thitung adalah 1,166 dan nilai sig adalah 0,246. Dengan demikian dapat dikatakan bahwa $t_{\text {hitung }}<t_{\text {tabel }}$ yaitu $1,166<1,98$ atau nilai signifikasi $0,246>0,05$. Nilai koefisien ${ }^{\beta \beta}$ dari variabel X2 bernilai Positif yaitu 1,166. Hal ini menunjukkan bahwa penelitian ini tidak dapat membuktikan 
reliability $\left(\mathrm{X}_{2}\right)$ berpengaruh positif terhadap tingkat kepuasan nasabah. Dengan demikian hipotesis pertama $\left(\mathrm{H}_{2}\right)$ ditolak.

Pengujian hipotesis dilakukan dengan membandingkan thitung dengan nilai $t_{\text {tabel }}$. Hipotesis diterima jika $t_{\text {hitung }}>t_{\text {tabel }}$ atau nilai sig $<0,05$. Nilai $t_{\text {abel }}$ pada 0,05 adalah 1,98. Untuk variabel responsiveness $\left(\mathrm{X}_{3}\right)$ nilai $\mathrm{t}_{\text {hitung }}$ adalah 1,635 dan nilai sig adalah 0,105. Dengan demikian dapat dikatakan bahwa $t_{\text {hitung }}<t_{\text {tabel }}$ yaitu 1,635 $<1,98$ atau nilai signifikasi $0,105>0,05$. Nilai koefisien $\beta \beta$ dari variabel X3 bernilai Positif yaitu 1,635. Hal ini menunjukkan bahwa penelitian ini tidak dapat membuktikan responsivenessy $\left(\mathrm{X}_{3}\right)$ berpengaruh positif terhadap tingkat kepuasan nasabah. Dengan demikian hipotesis pertama $\left(\mathrm{H}_{3}\right)$ ditolak.

Pengujian hipotesis dilakukan dengan membandingkan thitung dengan nilai $\mathrm{t}_{\text {tabel. }}$. Hipotesis diterima jika $\mathrm{t}_{\text {hitung }}>\mathrm{t}_{\text {tabel }}$ atau nilai sig $<0,05$. Nilai $\mathrm{tt}_{\text {abel }}$ pada 0,05 adalah 1,98. Untuk variabel assurance $\left(\mathrm{X}_{4}\right)$ nilai $\mathrm{t}_{\text {hitung }}$ adalah 11,987 dan nilai sig adalah 0,000. Dengan demikian dapat dikatakan bahwa $t_{\text {hitung }}>t_{\text {tabel }}$ yaitu 11,987 > 1,98 atau nilai signifikasi $0,000<0,05$. Nilai koefisien ${ }^{\beta \beta}$ dari variabel X4 bernilai Positif yaitu 11,987. Hal ini menunjukkan bahwa penelitian ini dapat membuktikan assurance $\left(\mathrm{X}_{4}\right)$ berpengaruh positif terhadap tingkat kepuasan nasabah. Dengan demikian hipotesis pertama $\left(\mathrm{H}_{4}\right)$ diterima.

Pengujian hipotesis dilakukan dengan membandingkan thitung dengan nilai $\mathrm{t}_{\text {tabel. }}$. Hipotesis diterima jika $\mathrm{t}_{\text {hitung }}>\mathrm{t}_{\text {tabel }}$ atau nilai sig $<0,05$. Nilai $\mathrm{tt}_{\text {abel }}$ pada 0,05 adalah 1,98. Untuk variabel empathy $\left(\mathrm{X}_{5}\right)$ nilai $\mathrm{t}_{\text {hitung }}$ adalah 5,683 dan nilai sig adalah 0,000. Dengan demikian dapat dikatakan bahwa $t_{\text {hitung }}>t_{\text {tabel }}$ yaitu 5,683 $>1,98$ atau nilai signifikasi $0,000<0,05$. Nilai koefisien $\beta \beta$ dari variabel X5 bernilai Positif yaitu 5,683. Hal ini menunjukkan bahwa penelitian ini dapat membuktikan empathy $\left(\mathrm{X}_{5}\right)$ berpengaruh positif terhadap tingkat kepuasan nasabah. Dengan demikian hipotesis pertama $\left(\mathrm{H}_{5}\right)$ diterima.

Penelitian ini bertujuan untuk melihat pengaruh tangible, reliability, responsiveness, assurance, dan empathy terhadap kepuasan nasabah SMS Banking bank nagari Capem Dr. M. Djamil Padang. Berdasarkan hasil penelitian dan pengujian hipotesis yang telah dilakukan maka hasil penelitian ini dapat disimpulkan: Tangible dalam pengujian hipotesis tidak berpengaruh signifikan terhadap kepuasan nasabah SMS bank nagari capem Dr. M. Djamil Padang

Reliability dalam pengujian hipotesis tidak berpengaruh signifikan terhadap kepuasan nasabah SMS bank nagari capem Dr. M. Djamil Padang

Responsiveness dalam pengujian hipotesis tidak berpengaruh signifikan terhadap kepuasan nasabah SMS bank nagari capem Dr. M. Djamil Padang

Assurance dalam pengujian hipotesis berpengaruh signifikan terhadap kepuasan nasabah SMS bank nagari capem Dr. M. Djamil Padang

Empathy dalam pengujian hipotesis berpengaruh signifikan terhadap kepuasan nasabah SMS bank nagari capem Dr. M. Djamil Padang 


\section{UCAPAN TERIMA KASIH}

Ucapan terima kasih untuk Bapak Febryandhie Ananda, SE,M.Si selaku ketua Sekolah Tinggi Ekonomi Keuangan Perbankan dan Pembangunan (STIE"KBP" Padang) beserta Staf pimpinan, karyawan dan karyawati di STIE"KBP" Padang Bapak Nazaruddin Azis,SE,MM selaku pembimbing dalam membantu penulis selama menuntut ilmu yang bermanfaat kepada penulis selama perkuliahan. Temanteman dan pihak-pihak lain yang membantu penulis dalam menyelesaikan skripsi ini yang tidak dapat penulis sebutkan satu persatu namanya.

\section{DAFTAR PUSTAKA}

Ali,A Hasyni.1992.Manajemen Bank.Jakarta: Bumi Aksara

Aziz, N. (2019). Pengaruh Komunikasi Efektif Terhadap Kepuasan Pelayanan Rumah Sakit Islam Siti Rahmah Padang. https://doi.org/10.17605/OSF.IO/T2H7Y

Cooper, Donald R dan Emory, C. William 1999. Metode Penelitian Bisnis. Edisi Kelima, Jilid Pertama. Jakarta: Penerbit Erlangga.

David L.Kurtz.2010.Principle of Contemporary Marketing, 14th Edition.China: South Western

Fernandes, Y. D., \& Marlius, D. (2018). Peranan Customer Service Dalam Meningkatkan Pelayanan Kepada Nasabah Pada PT. Bank Pembangunan Daerah Sumatera Barat Cabang Utama Padang. https://doi.org/10.31227/osf.io/wrh3p

Ferrel O.C \& Michael D. Hartline.2011.Marketing Management Strategies, Fifth Edition Canada: South Western

Gerson, Richard.2002.Mengukur Kepuasan Pelanggan:Panduan Menciptakan Pelayanan Bermut.Jakarta:PPM

John C. Mowen dan Michael Minor.2002.Perilaku Konsumen, Edisi Kelima, Jilid 2.Jakarta: Penerbit Erlangga

Khotler, Philip.2000.Manajemen Pemasaran : Analisis, Perencanaan, Implemntasi dan Kontrol, terjemahan : Hendra Teguh dan Ronny Antonius Rusly, Edisi 9, Jilid 1 dan 2, Jakarta:PT Prehelindo

Manurung,Mandala.2004.Uang,Perbankan,dan Ekonomi Moneter.Jakarta:Fakultas Ekonomi Universitas Indonesia 
Marlius, D. (2018). Loyalitas Nasabah Bank Nagari Syariah Cabang Bukittinggi Dilihat Dari Kualitas Pelayanan. Jurnal Pundi. Volume 1. No. 3. Hal.12-22. https://doi.org/10.31575/jp.v1i3.60

Marlius, D. (2018). Pengaruh Dimensi Kualitas Pelayanan Website Akademik Terhadap Kepuasan Mahasiswa Pada STIE “KBP”. Jurnal Ipteks Terapan. Volume 12. No. 2. Hal. 116-128. http://doi.org/10.22216/jit.2018.v12i2.633

Mirawati \& Fernos, J. (2019). Peranan Customer Service Dalam Meningkatkan Pelayanan Terhadap Nasabah Pada Bank Nagari Cabang Siteba Padang. https://doi.org/10.31227/osf.io/cq458

Mullins, John W \& Orville C. Walker, JR.2010.Marketing Management: A Strategic Decision-Making Approach, Seventh Edition.New York:McGraw-Hill Companies Inc.

Parasuraman, A., Zeitmahl, Valerie A., dan Berry, Leonard L. .1985. "A Conceptual Model of Service Quality and its Implication for Futureresearch". Journal of Marketing. Vol. 49 (Fall): 41-50

Paul J. Peter dan Jerry C. Olson.2010.Consumer Behavior and Marketing Strategy, Ninth Edition.New York: McGraw-Hill Companies

Phillip Kotler dan Gary Armstrong.2008.Prinsip-Prinsip Pemasaran, Edisi Keduabelas, Jilid1 Jakarta: Penerbit Erlangga

Richard, Gerson.2002. Mengukur Kepuasan Pelanggan.Jakarta : PPM

Safitri, R. N., \& Marlius, D. (2017). Penerapan E-Banking Dalam Meningkatkan Jasa Dan Layanan Perbankan Di PT. Bank Rakyat Indonesia Cabang Padang. https://doi.org/10.31227/osf.io/gkv8t

Sentoso, Singgih.2001. Buku latian SPSS: Statistik Parametrik. Cetakan Kedua. Jakarta: Penerbit Elex Media Computindo.

Sinungan,Muchdarsyah.1994.Strategi Manajemen Bank Menghadapi Tahun 2000.Jakarta: PT Rineka Cipta

Sutojo,Siswanto.1997.Manajemen Terapan Bank.Jakarta: PT Pustaka Binaman Presindo 
Sunardi .2003. "Analisis Faktor yang Dipertimbangkan Nasabah dalam Mempersepsikan Kualitas Layanan Bank di Magelang". Jurnal Ekonomi Bisnis : Dian Ekonomi, Vol.IX, No. 1 (Maret), 69-80.

Suharto Abdul Majid.2009.Customer Service dalam Bisnis Jasa Transportasi Jakarta: PT. Rajagrafindo Persada

Susanti, F. W Ekazaputri. (2018). Service Performance Dan Kepuasan Sebagai Moderating Variabel Terhadap Loyalitas Nasabah Pada PT BPR Labuh Gunung Payakumbuh Jurnal Benefita: Ekonomi Pembangunan Manajemen Bisnis Dan Akuntansi. Volume 3. No. 3. Hal. 433444.http://doi.org/10.22216/jbe.v3i3.3472

Tiza, M. F., \& Susanti, F. (2019). Pengaruh Kualitas Pelayanan Terhadap Kepuasan Pelanggan, Studi kasus pada perusahaan JNE Cabang Padang. https://doi.org/10.31227/osf.io/hx87m

Tjiptono, Fandy. 2002. Strategi Pemasaran,Edisi-2. Yogyakarta:ANDI

Tjiptono, Fandy.2005. Pemasaran Jasa, Edisi-1.Jakarta:Banyumedia

Tjiptono,Fandy. 1997. Prinsip - prinsip Total Quality Service. Edisi Pertama. Yogyakarta: Penerbit Audi

Tjiptono, Fandy dan Diana, Anastasia .2000. TQM: Total Quality Management. Edisi Revisi. Yogyakarta: Penerbit ANDI

Veithzal,Andria Permata.2006.Credit Management Handbook.Jakarta: PT Raja Grafindo Persada

Yamit .2001.Manajemen Kualitas Produk Dan Jasa. Yogyakarta: Ekonisia 